Article

\title{
Evaluation of Seven Essential Oils as Seed Treatments against Seedborne Fungal Pathogens of Cucurbita maxima
}

\author{
Marwa Moumni ${ }^{1,2}{ }^{\infty}$, Mohamed Bechir Allagui ${ }^{2} \oplus$, Kaies Mezrioui ${ }^{1,2}$, Hajer Ben Amara ${ }^{2}$ \\ and Gianfranco Romanazzi $1, *$ (D) \\ 1 Department of Agricultural, Food and Environmental Sciences, Marche Polytechnic University, \\ 60131 Ancona, Italy; m.moumni@staff.univpm.it (M.M.); kaismezrioui@yahoo.fr (K.M.) \\ 2 Laboratory of Plant Protection, National Institute for Agronomic Research of Tunisia, University of Carthage, \\ 2080 Ariana, Tunisia; allagui.bechir@gmail.com (M.B.A.); mzbenamara@gmail.com (H.B.A.) \\ * Correspondence: g.romanazzi@univpm.it; Tel.: +39-071-2204336
}

Citation: Moumni, M.; Allagui, M.B.; Mezrioui, K.; Ben Amara, H.;

Romanazzi, G. Evaluation of Seven Essential Oils as Seed Treatments against Seedborne Fungal Pathogens of Cucurbita maxima. Molecules 2021, 26, 2354. https://doi.org/10.3390/ molecules26082354

Academic Editor: Vincenzo De Feo

Received: 22 March 2021

Accepted: 14 April 2021

Published: 18 April 2021

Publisher's Note: MDPI stays neutral with regard to jurisdictional claims in published maps and institutional affiliations.

Copyright: (c) 2021 by the authors. Licensee MDPI, Basel, Switzerland. This article is an open access article distributed under the terms and conditions of the Creative Commons Attribution (CC BY) license (https:// creativecommons.org/licenses/by/ $4.0 /)$.

\begin{abstract}
Essential oils are gaining interest as environmentally friendly alternatives to synthetic fungicides for management of seedborne pathogens. Here, seven essential oils were initially tested in vivo for disinfection of squash seeds (Cucurbita maxima) naturally contaminated by Stagonosporopsis cucurbitacearum, Alternaria alternata, Fusarium fujikuro, Fusarium solani, Paramyrothecium roridum, Albifimbria verrucaria, Curvularia spicifera, and Rhizopus stolonifer. The seeds were treated with essential oils from Cymbopogon citratus, Lavandula dentata, Lavandula hybrida, Melaleuca alternifolia, Laurus nobilis, and Origanum majorana (\#1 and \#2). Incidence of S. cucurbitacearum was reduced, representing a range between $67.0 \%$ in L. nobilis to $84.4 \%$ in O. majorana \#2. Treatments at $0.5 \mathrm{mg} / \mathrm{mL}$ essential oils did not affect seed germination, although radicles were shorter than controls, except with $C$. citratus and O. majorana \#1 essential oils. Four days after seeding, seedling emergence was $20 \%, 30 \%$, and $10 \%$ for control seeds and seeds treated with $C$. citratus essential oil $(0.5 \mathrm{mg} / \mathrm{mL})$ and fungicides ( $25 \mathrm{~g} / \mathrm{L}$ difenoconazole plus $25 \mathrm{~g} / \mathrm{L}$ fludioxonil). S. cucurbitacearum incidence was reduced by $\sim 40 \%$ for plantlets from seeds treated with $C$. citratus essential oil. These data show the effectiveness of this essential oil to control the transmission of $S$. cucurbitacearum from seeds to plantlets, and thus define their potential use for seed decontamination in integrated pest management and organic agriculture.
\end{abstract}

Keywords: essential oils; Cymbopogon citratus; seedborne pathogens; squash; Stagonosporopsis cucurbitacearum

\section{Introduction}

Disease management is one of the biggest challenges for quantity and quality of crop production. As pathogen infections can be difficult to control, early treatments with antimicrobial compounds are often used to provide disease prevention. Cucurbita spp. can be affected by many fungal diseases, such as gummy stem blight (caused by Stagonosporopsis cucurbitacearum), Fusarium fruit rot (caused by Fusarium solani f. sp. cucurbitae), Alternaria leaf spot (caused by Alternaria alternata, Alternaria cucumerina) [1-4], and bacterial spot of pumpkin (caused by Xanthomonas cucurbitae) [5], along with viral diseases, including squash mosaic virus [6]. All of these pathogens that are responsible for the main diseases on cucurbits can be carried on seeds. This association between seeds and pathogens is an important means for the pathogens to spread on a large scale and a way to guarantee their survival in nature [7-9]. Seedborne pathogens can limit the production of many crops and can result in severe economic losses to growers [10-13].

Almost $90 \%$ of the world's food crops are grown from seed [14], and so sowing healthy seeds is essential to improve crop yields and increase food production [15]. With the need to guarantee high-quality seeds, seed treatments with antimicrobials represent a crucial and important step for reduction of seed infections [16]. Integrated pest management strategies are designed to provide environmentally sound and economically feasible alternatives for 
seedborne disease management [17]. These strategies are needed to minimize the inoculum of potential pathogens on seeds, and they draw on management components that are currently available to farmers, or can be made available in the near future [18].

Several studies have reported in vitro activities of essential oils and plant extracts against fungal and bacterial plant pathogens [19-22]. However, few have focused on in vivo activities of essential oils against seedborne fungi [23,24]. However, with many pathogens managed using fungicides, some of them have developed resistance to various fungicides that were previously very effective [25-29]. Stagonosporopsis spp. are devastating fungal pathogens of cucurbits and can lead to severe yield losses. These pathogens are major seedborne fungi of pumpkin and the dominant fungal cause of pumpkin seedling gummy stem blight $[11,30]$. No commercial cultivars with resistance to gummy stem blight are available, and so this disease has been frequently managed by fungicides application. As a result, several fungicides have lost their effectiveness against this disease following the development of resistance by S. cucurbitacearum $[28,31]$. Therefore, the development of alternative strategies to the use of synthetic fungicides for seed treatments is essential for both integrated pest management and organic agriculture.

Among the alternatives to synthetic fungicides, essential oils have gained interest for such plant disease management [32]. Indeed, lemongrass essential oil (Cymbopogon citratus) was shown to provide $100 \%$ inhibition of mycelial growth of S. cucurbitacearum [22,33]. Moreover, Dalcin et al. [34] reported that treatment with a low concentration of lemongrass essential oil $(<0.3 \%)$ reduced the severity of S. cucurbitacearum infections in melon plants.

The aims of the present study were to investigate the effectiveness of seed treatments with seven essential oils against the major seedborne fungi of squash. Furthermore, we investigated whether the treatment of seeds with C. citratus essential oil can control the transmission of S. cucurbitacearum from seeds to plantlets.

\section{Results}

\subsection{Efficacy of Essential Oils in the Control of Seed Infections}

Seven essential oils were used for seed treatments, initially at the three concentrations of $0.25,0.5$, and $1 \mathrm{mg} / \mathrm{mL}$ essential oils, using the standard blotter assay. The results show that these essential oils significantly reduced the incidence of infected seeds relative to the negative controls (Figure 1). The Cymbopogon citratus and Lavandula dentata essential oils at $0.5 \mathrm{mg} / \mathrm{mL}$ and $1 \mathrm{mg} / \mathrm{mL}$ were highly effective against incidence of infected seeds (ranged from $77.0-88.5 \%$ ), compared to the similar levels achieved by the fungicide treatment $(96.5 \%)$. Moreover, the incidence of infected seeds was significantly reduced by treatments at $1 \mathrm{mg} / \mathrm{mL}$ with Lavandula hybrida, Melaleuca alternifolia, Laurus nobilis, and the two Origanum majorana (\#1 and \#2) essential oils, by $66.5 \%, 59.8 \%, 65.5 \%, 54.1 \%$, and $73.5 \%$, respectively. Furthermore, the effects on the incidence of seed infections of these seven essential oils at $0.5 \mathrm{mg} / \mathrm{mL}$ and $1 \mathrm{mg} / \mathrm{mL}$ were not significantly different across the essential oils $(p>0.05)$.

\subsection{Effects of $0.5 \mathrm{mg} / \mathrm{mL}$ Essential Oils on Seed Germination, Radicle Length, and Individual Fungal Seed Infections}

The effects of $0.5 \mathrm{mg} / \mathrm{mL}$ essential oils were then studied in terms of seed germination and radicle length, and for the seed infections by the individual fungi in the blotter assays. 

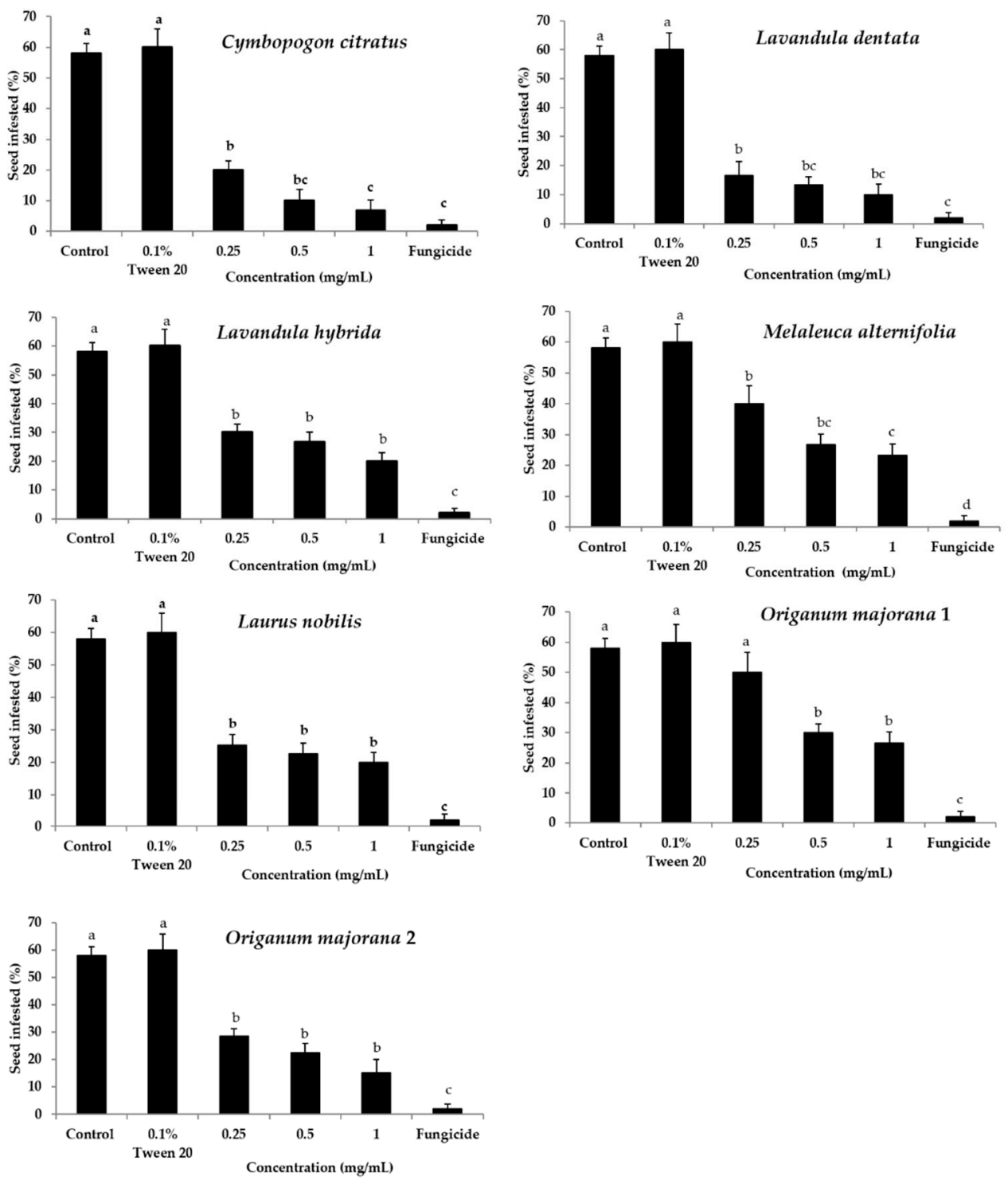

Figure 1. Incidence of infected seeds after treatments with sterile distilled water (negative control), $0.1 \%$ Tween 20, three concentrations of the seven essential oils (as indicated), and the fungicides combination ( $25 \mathrm{~g} / \mathrm{L}$ difenoconazole plus $25 \mathrm{~g} / \mathrm{L}$ fludioxonil; positive control), assayed using the blotter method. Data are means \pm standard error $(n=10 ; 10$ seeds/treatment/concentration). Means with different letters are significantly different ( $p \leq 0.05$; Fisher's LSD tests).

From the initial data in Figure 1 and considering the rates of the individual fungal infections of the seeds from the blotter assays in Table 1, it can be seen that the treatments with the essential oils did protect against the potential for seedborne infections compared with the controls. As shown in Table 1, in the control, seeds the pathogen S. cucurbitacearum was frequently revealed to be carried by the seeds in the blotter assay (Table 1,16.1\%); this incidence rate was significantly reduced for this fungus for all of the seed treatments with the essential oils (overall mean incidence, $4.4 \%$; overall inhibition, $\sim 73 \%$ ). In addition, the most effective of the essential oils were $O$. majorana $\# 2$ and $M$. alternifolia, which significantly reduced seed infections by S. cucurbitacearum by $84.5 \%$ and $75.8 \%$, respectively. These effects were also not significantly different compared to the seed treatment with the fungicides $(98.8 \%)$. For the seeds that carried A. alternata, there were significant reductions for the seed treatments by the seven essential oils that ranged from $71.0 \%$ (O. majorana \#1) to $89.3 \%$ (L. dentata and L. nobilis), again with no significant differences between the seeds treated with the essential oils and the fungicides. Fusarium fujikuroi was the most frequent fungus on 
the control seeds (incidence $22.6 \%$ ) and considerably significantly reduced by the essential oils, in particular with the C. citratus and L. dentata essential oil treatments, by $76.6 \%$ and $89.4 \%$, respectively, with these treatments also showing no significant differences compared to the seeds treated with the fungicides. All of the essential oils were also significantly effective against $F$. solani (except L. hybrida, at a non-significant $34.8 \%$ inhibition), with reductions of seed infections from $89.1-100 \%$. The incidence of Paramyrothecium roridum was also significantly reduced for all of the seeds treated with the essential oils. Again, these effects were not significantly different between the essential oils, where the most effective inhibition appeared to be with M. alternifolia $(87.9 \%)$, L. dentata $(82.8 \%)$, and $O$. majorana \#1 (82.8\%), with this fungus completely removed by the fungicides. The incidence of Albifimbria verrucaria on the seeds was significantly reduced by the C. citratus, L. hybrida, L. nobilis, and O. majorana \#2 essential oils, by $84.9 \%, 93.9 \%, 69.7 \%$, and $69.7 \%$, respectively. Instead, the inhibition by the remaining essential oils did not reach significance over the control (L. dentata, M. alternifolia, and O. majorana \#1, all at 48.5\%). For the seeds infected by Curvularia spicifera, there were reductions across these seven essential oils from $63.6 \%$ (O. majorana \#1) to $100 \%$ (L. dentata), with relatively low, but not significantly different, inhibition seen for the fungicides $(69.7 \%)$. Rhizopus stolonifer was significantly reduced by similar amounts in all of the seeds treated with the essential oils. The most effective here appeared to be L. dentata $(77.4 \%)$ and C. citratus $(74.4 \%)$, and the least effective were the two O. majorana essential oils (\#1 and \#2: 50.6\%, 49.4\%, respectively); the fungicides showed $93.9 \%$ inhibition here.

The effects of the treatments with the seven essential oils at $0.5 \mathrm{mg} / \mathrm{mL}$ on seed germination and radicle length are also shown in Table 1. No significant differences in germination rates were seen between the control seeds and the seeds treated with the different essential oils. On the other hand, the germination of the seeds treated with the fungicide combination ( $25 \mathrm{~g} / \mathrm{L}$ difenoconazole and $25 \mathrm{~g} / \mathrm{L}$ fludioxonil) was significantly reduced, by $11.5 \%$, compared to the control. Moreover, for the radicle length, these data showed that the $C$. citratus and O. majorana \#1 essential oils did not have any significant effects compared with the control. However, the radicle lengths of the seeds treated with the L. dentata, L. hybrida, M. alternifolia, L. nobilis, and O. majorana \#2 essential oils were significantly decreased by $28.2 \%, 23.4 \%, 34.5 \%, 25.8 \%$, and $27.8 \%$, respectively. On the contrary, compared to the control, the radicle length of the seeds treated with the fungicides was significantly increased, by $24.4 \%$.

\subsection{Effects ofCymbopogon citratus Essential Oil on Plantlets}

Seed treatments with $0.5 \mathrm{mg} / \mathrm{mL}$ C. citratus essential oil significantly increased the seedling emergence $(p<0.002)$ in comparison to the control and the fungicides treatments. Four days after sowing, the seeds treated with the C. citratus essential oil showed 30\% emergence, while the control treatment $(0.1 \%$ Tween 20$)$ and the fungicides treatment showed $20 \%$ and $10 \%$ emergence, respectively. In particular, these data demonstrated that the seeds treated with the fungicides took longer to emerge (Figure 2).

Forty days after seeding, compared to the control, these seed treatments with the $C$. citratus essential oil and the fungicides were effective for significant improvements in the plantlet lengths $(23.3 \mathrm{~cm}$ vs. $30.5 \mathrm{~cm}, 30.2 \mathrm{~cm}$, respectively; Table 2). These seeds treated with the C. citratus essential oil also resulted in significant reduction of $S$. cucurbitacearum on the plantlets $(39.9 \% ; p<0.001)$ compared to the control (Table 2; Figure 3). In this assessment, the infections of the plantlet leaves, stems, and roots with $S$. cucurbitacearum were not significantly different between the C. citratus essential oil and fungicide treatments, which both showed significant improvements over the control. 
Table 1. Effects of the seven essential oils at $0.5 \mathrm{mg} / \mathrm{mL}$ and the fungicides on seed germination, radicle length, and incidence of seed infections by the individual fungi.

\begin{tabular}{|c|c|c|c|c|c|c|c|c|c|c|}
\hline \multirow{2}{*}{$\begin{array}{c}\text { Treatment/ } \\
\text { Essential Oil }\end{array}$} & \multirow{2}{*}{$\begin{array}{c}\text { Germination } \\
(\%)\end{array}$} & \multirow{2}{*}{$\begin{array}{c}\text { Radicle } \\
\text { Length }(\mathrm{cm})\end{array}$} & \multicolumn{8}{|c|}{ Incidence of Seed Infection (\%) ${ }^{c}$} \\
\hline & & & S.c. & A.a. & F.f. & F.s. & P.r. & A.v. & C.s. & R.s. \\
\hline Control $^{\mathrm{a}}$ & $85 \pm 1.4^{\mathrm{a}}$ & $20.9 \pm 0.7^{b}$ & $16.1 \pm 2.3^{\mathrm{a}}$ & $9.3 \pm 1.8^{a}$ & $22.6 \pm 2.4^{\mathrm{a}}$ & $4.6 \pm 1.0^{\mathrm{a}}$ & $5.8 \pm 1.6^{\mathrm{a}}$ & $3.3 \pm 1.6^{a}$ & $3.3 \pm 1.7^{\mathrm{a}}$ & $16.4 \pm 3.9^{\mathrm{a}}$ \\
\hline C. citratus & $86 \pm 1.9^{a}$ & $21.0 \pm 0.9^{b}$ & $4.5 \pm 0.9^{b}$ & $1.1 \pm 0.5^{\mathrm{c}}$ & $5.3 \pm 1.2^{\mathrm{c}, \mathrm{d}}$ & $0.5 \pm 0.3^{b}$ & $1.7 \pm 0.6^{\mathrm{b}}$ & $0.5 \pm 0.3^{b}$ & $0.9 \pm 0.4^{b}$ & $4.2 \pm 1.4^{\mathrm{b}, \mathrm{c}}$ \\
\hline L. dentata & $86 \pm 1.7^{\mathrm{a}}$ & $15.0 \pm 0.7^{c}$ & $5.2 \pm 1.2^{b}$ & $1.0 \pm 0.4^{\mathrm{c}}$ & $2.4 \pm 0.8^{\mathrm{c}, \mathrm{d}}$ & $0.5 \pm 0.5^{b}$ & $1.0 \pm 0.0^{b}$ & $1.7 \pm 0.6^{\mathrm{a}, \mathrm{b}}$ & $0.0 \pm 0.0^{b}$ & $3.7 \pm 1.1^{\mathrm{b}, \mathrm{c}}$ \\
\hline L. hybrida & $85 \pm 2.2^{a}$ & $16.0 \pm 0.6^{\mathrm{c}}$ & $4.3 \pm 0.9^{b}$ & $2.3 \pm 0.8^{c}$ & $8.0 \pm 1.4^{\mathrm{c}}$ & $3.0 \pm 1.6^{\mathrm{a}}$ & $2.3 \pm 0.8^{b}$ & $0.2 \pm 0.2^{b}$ & $1.0 \pm 0.6^{b}$ & $6.1 \pm 1.9^{b, c}$ \\
\hline M. alternifolia & $85 \pm 2.4^{\mathrm{a}}$ & $13.7 \pm 0.7^{\mathrm{c}}$ & $3.9 \pm 1.2^{b, c}$ & $1.7 \pm 0.6^{c}$ & $7.9 \pm 1.3^{c}$ & $0.0 \pm 0.0^{b}$ & $0.7 \pm 0.4^{b}$ & $1.7 \pm 0.8^{\mathrm{a}, \mathrm{b}}$ & $0.2 \pm 0.2^{b}$ & $7.6 \pm 2.0^{b, c}$ \\
\hline L. nobilis & $86 \pm 1.9^{a}$ & $15.5 \pm 0.6^{\mathrm{c}}$ & $5.3 \pm 1.1^{b}$ & $1.0 \pm 0.4^{\mathrm{c}}$ & $9.3 \pm 1.4^{b, c}$ & $0.5 \pm 0.3^{b}$ & $1.2 \pm 0.5^{b}$ & $1.0 \pm 0.4^{\mathrm{b}}$ & $0.7 \pm 0.4^{b}$ & $6.3 \pm 1.8^{b, c}$ \\
\hline O. majorana & $85 \pm 1.4^{\mathrm{a}}$ & $15.1 \pm 0.7^{\mathrm{c}}$ & $2.5 \pm 0.7^{b, c}$ & $1.2 \pm 0.5^{c}$ & $10.1 \pm 1.6^{\mathrm{b}}$ & $0.0 \pm 0.0^{b}$ & $1.7 \pm 0.6^{b}$ & $1.0 \pm 0.4^{\mathrm{b}}$ & $0.3 \pm 0.3^{b}$ & $8.3 \pm 2.4^{b}$ \\
\hline Fungicides $b$ & $75 \pm 2.2^{b}$ & $26.0 \pm 1.1^{\mathrm{a}}$ & $0.2 \pm 0.2^{c}$ & $0.0 \pm 0.0^{c}$ & $1.21 \pm 0.5^{\mathrm{d}}$ & $0.0 \pm 0.0^{b}$ & $0.0 \pm 0.0^{b}$ & $0.0 \pm 0.0^{b}$ & $1.0 \pm 0.0^{b}$ & $1.0 \pm 0.0^{\mathrm{c}}$ \\
\hline Significance $(p)$ & 0.001 & $<0.001$ & $<0.001$ & $<0.001$ & $<0.001$ & $<0.001$ & 0.002 & 0.025 & 0.032 & $<0.001$ \\
\hline
\end{tabular}

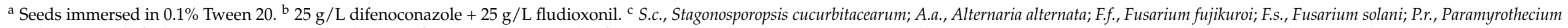

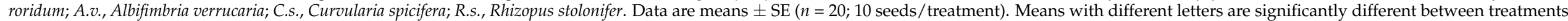
(down columns) ( $p \leq 0.05 ;$ Fisher's LSD). 
Table 2. Effects of $0.5 \mathrm{mg} / \mathrm{mL}$ Cymbopogon citratus essential oil and the fungicides $(25 \mathrm{~g} / \mathrm{L}$ difenoconazole, $25 \mathrm{~g} / \mathrm{L}$ fludioxonil) on squash plantlets and their incidence of Stagonosporopsis cucurbitacearum after 40 days of seeding at room temperature $\left(22 \pm 2{ }^{\circ} \mathrm{C}\right)$.

\begin{tabular}{cccccc}
\hline \multirow{2}{*}{ Treatment } & \multicolumn{2}{c}{ Plantlet } & \multicolumn{2}{c}{$\begin{array}{c}\text { Disease Incidence of Stagonosporopsis } \\
\text { cucurbitacearum on the Plantlets (\%) }\end{array}$} \\
\cline { 2 - 5 } & Length (cm) & Infection (\%) & Leaves & Stems & Roots \\
\hline Control $^{\mathrm{a}}$ & $23.3 \pm 1.2^{\mathrm{a}}$ & $49.9 \pm 2.9^{\mathrm{c}}$ & $30.3 \pm 5.2^{\mathrm{b}}$ & $43.0 \pm 4.4^{\mathrm{b}}$ & $43.1 \pm 3.2^{\mathrm{b}}$ \\
${\text { C. } \text { citratus }^{\mathrm{a}}}^{\mathrm{a}}$ & $30.5 \pm 1.1^{\mathrm{b}}$ & $30.0 \pm 4.4^{\mathrm{b}}$ & $18.7 \pm 3.3^{\mathrm{a}}$ & $28.3 \pm 4.5^{\mathrm{a}}$ & $18.1 \pm 4.3^{\mathrm{a}}$ \\
Fungicide $^{\mathrm{b}}$ & $30.2 \pm 1.2^{\mathrm{b}}$ & $16.8 \pm 1.9^{\mathrm{a}}$ & $9.7 \pm 1.6^{\mathrm{a}}$ & $17.3 \pm 1.9^{\mathrm{a}}$ & $17.0 \pm 2.1^{\mathrm{a}}$ \\
\hline
\end{tabular}

a Seeds immersed in $0.1 \%$ Tween $20 .^{\mathrm{b}} 25 \mathrm{~g} / \mathrm{L}$ difenoconazole $+25 \mathrm{~g} / \mathrm{L}$ fludioxonil. Data are means \pm SE $(n=5$ 10 seeds/treatment). Data with different letters are significantly different between treatments (down columns) $(p \leq 0.05 ;$ Fisher's LSD).

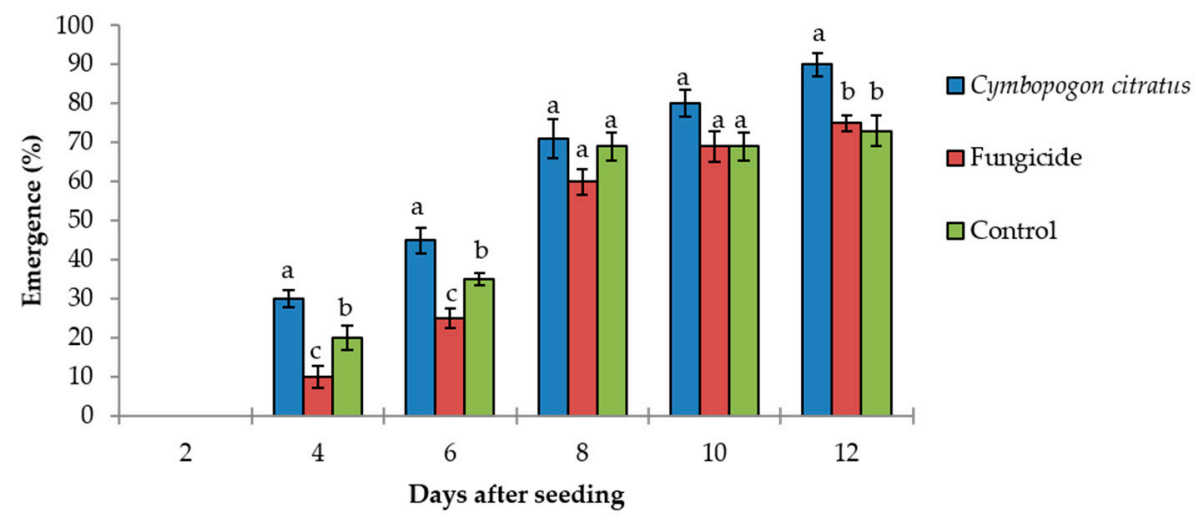

Figure 2. The effects of $0.5 \mathrm{mg} / \mathrm{mL}$ Cymbopogon citratus essential oil and fungicides $(25 \mathrm{~g} / \mathrm{L}$ difenoconazole plus $25 \mathrm{~g} / \mathrm{L}$ fludioxonil) on seedling emergence. Control, seeds immersed in $0.1 \%$ Tween 20. Data are means \pm standard error ( $n=5 ; 10$ seeds/treatment). Means with different letters are significantly different ( $p \leq 0.05$; Fisher's LSD tests).

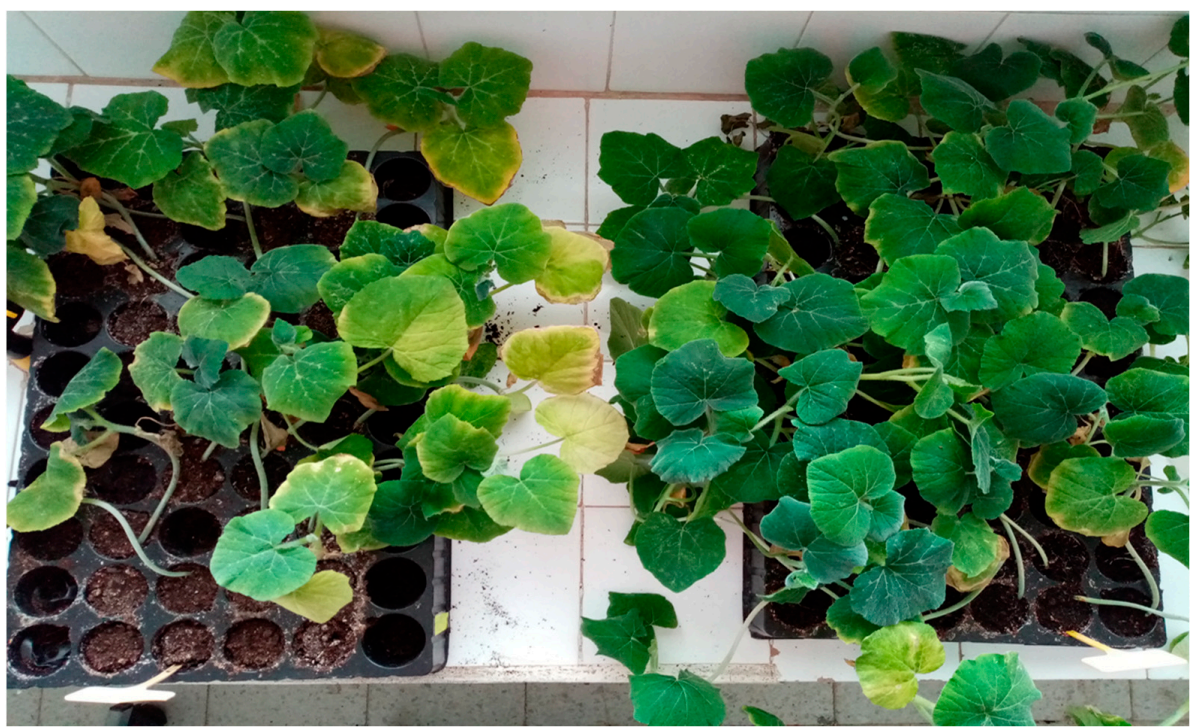

Figure 3. Gummy stem blight symptoms on squash plantlets. Control (left) and seeds treated with $0.5 \mathrm{mg} / \mathrm{mL}$ Cymbopogon citratus essential oil (right) 30 days from seeding, with plants kept at room temperature $\left(22 \pm 2{ }^{\circ} \mathrm{C}\right)$.

\section{Discussion}

Seeds are critical for the production of viable crops. The use of pathogen-free seeds is generally recommended as the primary management strategy for the generation of healthy 
plant populations and for good harvest yields [13,18,35]. Integrated pest management strategies can provide more environmentally sound and economically feasible alternatives for the management of seedborne diseases. These strategies are needed to minimize the potential inoculum of pathogens being carried on seeds, by drawing on management components that are currently available to farmers, or can be made available in the near future [18]. However, there remains a lack of information about the effectiveness of seed treatments with essential oils against fungal diseases of $C$. maxima.

The present study was performed in a controlled environment where seven essential oils were shown to be effective against the main seedborne fungi when applied to squash seeds that were naturally infected. The seed treatments with the M. alternifolia and $O$. majorana \#2 essential oils showed excellent activities against the $S$. cucurbitacearum and F. solani pathogens, with $F$. solani completely inhibited. These high antifungal activities of these two essential oils in particular appear to be the result of the high content of the monoterpene alcohol terpinen-4-ol, which in previous studies has shown good antifungal activity against Fusarium spp. [36,37].

Antifungal properties of essential oils towards Fusarium spp. have been reported in a number of previous studies, for different laboratory media and plant materials [38-40]. Perczak et al. [41] reported that essential oils have great potential for inhibition of growth of Fusarium fungi on maize seeds. An O. majorana essential oil was shown to have antifungal activities against four seedborne fungi in rice: Fusarium verticilliodies, Fusarium graminearum, Bipolaris oryzae, and Curvularia lunata [42]. Van der Wolf et al. [43] showed that thyme, oregano, cinnamon, and clove essential oils can reduce fungi on cabbage seeds, using the blotter method. Riccioni et al. [24] reported the efficacy of a tea tree essential oil to reduce Ascochyta blight in pea seeds. Their seed treatments with $L$. nobilis and $L$. dentata essential oils showed significant reductions of $A$. alternata. These two essential oils were characterized by high eucalyptol as their main volatile component. Xu et al. [44] showed excellent antifungal activity of a L. nobilis essential oil when tested against $A$. alternata. In addition, $\mathrm{Xu}$ et al. [45] demonstrated that $0.5 \mathrm{mg} / \mathrm{mL}$ of their $L$. nobilis essential oil protected cherry tomatoes from infection with A. alternata.

The L. hybrida essential oil used in the present study was characterized previously to have relatively high content of linalool, followed by linalyl acetate and camphor [22]. Here, the $L$. hybrida essential oil showed moderate activity against seed infections. There were significant reductions in the $A$. verrucaria and $A$. alternata seed infections, although no significant reduction for F. solani compared to control. Daferera et al. [46] reported that the main compounds in their L. hybrida essential oil were linalyl acetate and linalool, and this essential oil showed less inhibitory activity against Botrytis cinerea and $F$. solani compared to oregano and thyme essential oils. The main compounds of a Salvia sclarea essential oil were also reported as linalyl acetate and linalool, and this essential oil showed good inhibitory activity against $A$. alternata [47]. Indeed, Kishore et al. [48] showed that linalool had the lowest inhibitory activity against A. alternata, C. lunata, Fusarium moniliforme, Fusarium pallidoroseum, and Fusarium udum. The same essential oil of $C$. citratus was shown to have the greatest inhibition of the growth of S. cucurbitacearum and A. alternata [22]. This activity has been confirmed in vivo in the present study, with reduction of the incidence of infection by the seedborne fungi for the plantlets following treatment of the seeds with the C. citratus essential oil. Chen et al. [49], demonstrated the effectiveness of a Cymbopogon nardus (citronella) essential oil on A. alternata in in vitro and in vivo assays. Eke et al. [50] reported that a C. citratus essential oil protected common bean plantlets from infection by $F$. solani, both in the laboratory and a greenhouse.

A normal germination rate of $>85 \%$ was seen here for all of the treated seeds, except with the fungicides. This confirms that these seven essential oils at concentration of $0.5 \mathrm{mg} / \mathrm{mL}$ are not phytotoxic to squash seed germination. Orzali et al. [51] showed also that an Origanum vulgare essential oil did not affect germination rates of tomato seeds. However, the concentration of essential oil and the immersion time of the seeds in the treatments are very important factors for phytotoxicity, as they can affect seed vitality $[52,53]$. In addition, here the $C$. citratus essential oil showed no significant inhibition 
of germination while it significantly inhibited the seed contamination, and unlike other essential oils here, C. citratus did not show significant shortening of the radicle length compared to the control following seed germination. For these reasons, this essential oil was selected in the final stages of this study, to be tested on the emergence and growth of the squash plantlets, and the disease incidence of $S$. cucurbitacearum for these plantlets.

Here, the seed treatment with $0.5 \mathrm{mg} / \mathrm{mL}$ C. citratus essential oil significantly increased the plantlet emergence, reduced the incidence of seedborne S. cucurbitacearum for the various parts of the plantlets, without any significant differences compared to the fungicides. Naveenkumar et al. [54] reported that for Oryza sativa (rice) seedlings, a C. citratus essential oil increased the seed germination, shoot length, root length, and vigor. Also, a C. citratus essential oil was shown to reduce the severity of S. cucurbitacearum infections in melon plants [34].

Therefore, the use of these seven essential oils might serve as alternatives to the use of synthetic fungicides for prevention and control of seedborne pathogens in commercially produced seeds. The results of this study on the seedborne fungi of squash are thus useful to go forward to set up strategies for an integrated pest management program.

\section{Materials and Methods}

\subsection{Collection of Squash Seed Samples}

Twenty-nine seed samples were collected from three regions in Tunisia (Siliana: $35^{\circ} 57^{\prime} 28^{\prime \prime}$ N, $9^{\circ} 32^{\prime} 57^{\prime \prime}$ E; Bizerte: $37^{\circ} 03^{\prime} 25^{\prime \prime}$ N, $10^{\circ} 03^{\prime} 43^{\prime \prime}$ E; and Kasserine: $35^{\circ} 14^{\prime} 00^{\prime \prime}$ N, $9^{\circ} 08^{\prime} 00^{\prime \prime}$ E). These seed samples were extracted from asymptomatic and symptomatic squash fruit (Cucurbita maxima, local variety cv. Bjaoui). These samples were evaluated for incidence of seedborne fungal pathogens, especially the main fungi: S. cucurbitacearum, A. alternata, and F. solani [4]. All of these seed samples were mixed and stored in paper bags at $4{ }^{\circ} \mathrm{C}$ until use in the experiments.

\subsection{Essential Oils}

The seven essential oils used in this study were provided by different laboratories (Table 3) and were initially evaluated under in vitro conditions against the main seedborne fungi of cucurbits (S. cucurbitacearum, and A. alternata) [22]. The main volatile compounds present in these essential oils were previously analyzed by gas chromatography-mass spectrometry [22] (Table 3).

Table 3. Details of the seven essential oils used in this study, including the two main volatile constituents defined through previous gas chromatography-mass spectrometry analysis [22].

\begin{tabular}{|c|c|c|c|c|}
\hline \multirow{2}{*}{ Species } & \multirow{2}{*}{ Common Name } & \multirow{2}{*}{ Source } & \multicolumn{2}{|c|}{ Two Main Components } \\
\hline & & & Compound & $(\%)$ \\
\hline \multirow{2}{*}{ Cymbopogon citratus } & \multirow{2}{*}{ Lemongrass } & \multirow{2}{*}{ CRRHAB } & $\alpha$-Citral & 51.6 \\
\hline & & & $\beta$-Citral & 26.0 \\
\hline \multirow{2}{*}{ Lavandula dentata } & \multirow{2}{*}{ Lavender } & \multirow{2}{*}{ CRRHAB } & Eucalyptol & 63.5 \\
\hline & & & $\beta$-Selinene & 4.1 \\
\hline \multirow{2}{*}{ Lavandula hybrida } & \multirow{2}{*}{ Lavandin } & FLORA s.r.l. & Linalool & 33.7 \\
\hline & & (Batch $\left.N^{\circ} 161808\right)$ & Camphor & 9.3 \\
\hline \multirow{2}{*}{ Melaleuca alternifolia } & \multirow{2}{*}{ Tea tree } & FLORA s.r.l. & Terpinen-4-ol & 41.1 \\
\hline & & (Batch $\left.N^{\circ} 161960\right)$ & $\gamma$-Terpinene & 16.0 \\
\hline \multirow{2}{*}{ Laurus nobilis } & \multirow{2}{*}{ Bay laurel } & \multirow{2}{*}{ INAT } & Eucalyptol & 47.9 \\
\hline & & & $\alpha$-Terpinyl acetate & 10.2 \\
\hline \multirow{2}{*}{ Origanum majorana } & \multirow{2}{*}{ Marjoram\#1 } & \multirow{2}{*}{ INAT } & Terpinen-4-ol & 32.4 \\
\hline & & & $\gamma$-Terpinene & 12.6 \\
\hline \multirow{2}{*}{ Origanum majorana } & \multirow{2}{*}{ Marjoram\#2 } & \multirow{2}{*}{ CRRHAB } & Terpinen-4-ol & 50.1 \\
\hline & & & p-Cymene & 17.8 \\
\hline
\end{tabular}

CRRHAB, Biopesticides Laboratory, Regional Centre for Research in Horticulture and Organic Agriculture, Sousse, Tunisia. FLORA s.r.l., Lorenzana, Pisa, Italy. INAT, Medicinal Plants Laboratory, National Institute of Agronomy of Tunisia, Tunisia. 


\subsection{Seed Treatments with the Essential Oils}

Before the treatments, naturally contaminated seeds were surface sterilized in $1 \%$ sodium hypochlorite solution for $5 \mathrm{~min}$, rinsed three times with sterilized distilled water, and air dried for $2 \mathrm{~h}$ on sterile paper towel in a laminar flow hood. For the seed treatments, the seven essential oils were dissolved in sterilized distilled water with $0.1 \%(v / v)$ Tween 20 (Sigma Aldrich, Steinheim, Germany), to obtain homogeneous emulsions. Three final concentrations for each essential oil were initially used to determine the most effective concentration: $0.25 \mathrm{mg} / \mathrm{mL}, 0.5 \mathrm{mg} / \mathrm{mL}$, and $1 \mathrm{mg} / \mathrm{mL}$ essential oils. The naturally infected seeds were immersed in $40 \mathrm{~mL}$ of each concentration of the essential oils, and in the fungicides (Celest Extra 17\%: $25 \mathrm{~g} / \mathrm{L}$ difenoconazole $+25 \mathrm{~g} / \mathrm{L}$ fludioxonil). In parallel, two negative controls were prepared of the seeds in sterile distilled water and in $0.1 \%$ Tween 20. These seed treatments were carried out for $6 \mathrm{~h}$, with mixing every $30 \mathrm{~min}$. Then, the seeds were dried on sterile blotter sheets overnight $(12 \mathrm{~h})$ at room temperature $\left(25-28{ }^{\circ} \mathrm{C}\right)$. The treated seeds were placed in glass Petri dishes that each contained eight pieces of sterile blotter paper (diameter, $110 \mathrm{~mm}$; Whatman no. 4 filter papers) that were moistened with $5 \mathrm{~mL}$ sterile distilled water. These were incubated for 14 days at $22 \pm 2{ }^{\circ} \mathrm{C}$ with a $12 / 12 \mathrm{~h}$ dark/ultraviolet light photoperiod (TL-D 36W BLB 1SL, Philips, Dublin, Ireland). To determine number of infected seeds, all Petri dishes were examined under a stereomicroscope (M125; Leica Microsystems CMS, Wetzlar, Germany). For each concentration of the different essential oils, 100 seeds were treated and the experimental trial was repeated twice.

To compare the efficacies of the different essential oils on the fungi of these naturally infecting seeds, the intermediary $0.5 \mathrm{mg} / \mathrm{mL}$ concentration was chosen. Here, 200 seeds were treated separately with each of the seven essential oils at $0.5 \mathrm{mg} / \mathrm{mL}$, as described above. Seeds immersed in $0.1 \%$ Tween 20 were used as the control. After 14 days of incubation, fungi identification was carried out first by examination of the fungal fruiting bodies and the congregated mycelia and spores on the seeds under a stereomicroscope (M125; Leica Microsystems CMS, Wetzlar, Germany). Then, the individual spores, conidiophores, and pycnidia were examined under a microscope (DM 2500; Leica). The fungal species identification was based on the keys of Mathur and Kongsdal [15] and Moumni et al. [4]. Assessments were based on relative frequencies of seedborne fungi, the germination rates of the seeds and the length of the growing radicle.

\subsection{Effects of Cymbopogon citratus Essential Oil on Emergence of Seedlings and Disease Incidence of S. cucurbitacearum of Squash Plantlets}

The naturally contaminated seeds were treated separately with the $C$. citratus essential oil at $0.5 \mathrm{mg} / \mathrm{mL}$ and with the fungicides ( $25 \mathrm{~g} / \mathrm{L}$ difenoconazole $+25 \mathrm{~g} / \mathrm{L}$ fludioxonil). Tween $20(0.1 \%)$ was used as the control. For each treatment, 50 seeds were used, according to the method described above, and the experimental trials were repeated twice. The treated seeds were sown on pasteurized soil in disinfected seedling trays. The seeds in the trays were incubated at room temperature $\left(22 \pm 2{ }^{\circ} \mathrm{C}\right)$. Seedling emergence was recorded based on the number of emerged seedlings every 2 days, up to 14 days after sowing. At 14 days after sowing, the dead and germinated seedlings were recorded. Then 40 days after sowing, the lengths of the plantlets were measured and recorded. At the same time, 30 symptomatic and asymptomatic plantlets from each treatment were collected randomly and sliced into their three major parts—-the leaves, stems, and roots—using a flame-sterilized scalpel, to determine the incidence of S. cucurbitacearum infection for each part. Each vegetative section was surface-disinfected in 1\% sodium hypochlorite for $2 \mathrm{~min}$, rinsed three times in sterile distilled water, and dried on sterile blotter paper. Each part was cut into pieces of about $2 \mathrm{~mm}$, plated on potto dextrose agar, and assessed for fungal colony development after 7 days of incubation at $22 \pm 2{ }^{\circ} \mathrm{C}$. Morphological identification of the colonies was carried out to determine S. cucurbitacearum growth. The proportions of S. cucurbitacearum transmission (Sct) we calculated based on Equation (1): 


\subsection{Statistical Analysis}

Analysis of variance was calculated using SPSS (version 20; IBM, Armonk, NY, USA). The data for incidence of infected seeds, germination rates, radicle lengths, plantlet infection, and plantlet lengths underwent analysis of variance (ANOVA). Means were compared using Fisher's tests for protected least significant difference (LSD) at $p \leq 0.05$. All of the trials were repeated at least twice, and the data are given as means \pm standard error (SE). The following sample sets were used: 10 replicates of 10 seeds for the effects of the essential oils on disease incidence at three concentrations; 20 replicates of 10 seeds from each treatment to determine the effect of treatments on infected seeds at $0.5 \mathrm{mg} / \mathrm{mL}$; and 5 replicates of 10 seeds from each treatment to determine the effect of $C$. citratus on emergence of seedling and disease incidence on the plantlets.

\section{Conclusions}

This study investigated the in vivo antifungal activities of seven essential oils towards seedborne pathogens of cucurbits. The results show that the essential oils are effective to reduce multiple pathogens on squash seeds. The C. citratus essential oil increased seedling emergence and reduced the incidence of S. cucurbitacearum in plantlets.

Seed treatments with essential oils can contribute to effective management of seedborne fungi on cucurbits under integrated and organic agriculture. These strategies are needed to minimize the inoculum of potential pathogens on seeds, and can be available in the future. The success of the application of such nonchemical alternatives requires an integrated approach that involves the combination of multiple control strategies according to the localization of the pathogen on the seeds. These methods of alternative strategies now need to be further developed as relevant pest management tools for sustainable agricultural production.

Author Contributions: Conceptualization, G.R., M.M., and M.B.A.; methodology, M.M., M.B.A., K.M., and H.B.A.; software, M.M.; validation, M.M. and M.B.A.; formal analysis, M.M. and M.B.A.; investigation, M.M. and M.B.A.; resources, M.M., K.M., and M.B.A.; data curation, M.M.; writingoriginal draft preparation, M.M. and K.M.; writing-review and editing, M.M., G.R., and M.B.A.; visualization, G.R., M.M., and M.B.A.; supervision, G.R. and M.B.A. All authors have read and agreed to the published version of the manuscript.

Funding: This research received no external funding.

Institutional Review Board Statement: Not applicable.

Informed Consent Statement: Not applicable.

Data Availability Statement: The data presented in this study are available on request from the corresponding author.

Acknowledgments: The company FLORA s.r.l., Italy; Regional Centre for Research in Horticulture and Organic Agriculture (CRRHAB), Tunisia; and National Institute of Agronomy of Tunisia (INAT), Tunisia, are acknowledged for kindly providing essential oils used here.

Conflicts of Interest: The authors declare that they have no conflict of interest.

Sample Availability: Samples of the compounds are available from the authors.

\section{References}

1. Gannibal, P.B. Alternaria cucumerina causing leaf spot of pumpkin newly reported in north caucasus (Russia). New Dis. Rep. 2011, 23, 36. [CrossRef]

2. Keinath, A.P. From native plants in central Europe to cultivate crops worldwide: The emergence of Didymella bryoniae as a cucurbit pathogen. HortScience 2011, 46, 532-535. [CrossRef]

3. Mehl, H.L.; Epstein, L. Identification of Fusarium solani f. sp. cucurbitae race 1 and race 2 with PCR and production of disease-free pumpkin seeds. Plant Dis. 2007, 91, 1288-1292. [CrossRef]

4. Moumni, M.; Allagui, M.B.; Mancini, V.; Murolo, S.; Tarchoun, N.; Romanazzi, G. Morphological and molecular identification of seedborne fungi in squash (Cucurbita maxima, Cucurbita moschata). Plant Dis. 2020, 104, 1335-1350. [CrossRef] 
5. Zhang, X.; Babadoost, M. Characteristics of Xanthomonas cucurbitae isolates from pumpkins and survival of the bacterium in pumpkin seeds. Plant. Dis. 2018, 9, 1779-1784. [CrossRef]

6. Li, R.; Gao, S.; Berendsen, S.; Fei, Z.; Ling, K.S. Complete genome sequence of a novel genotype of Squash mosaic virus infecting squash in Spain. Genome Announc. 2015, 3, e01583-14. [CrossRef]

7. Ahmad, L.; Pathak, N.; Zaidi, R.K. Antifungal potential of plant extracts against seed-borne fungi isolated from barley seeds (Hordeum vulgare L.). J. Plant Pathol. Microbiol. 2016, 7, 350. [CrossRef]

8. Özer, N.; Coşkuntuna, A. The Biological Control Possibilities of Seed-Borne Fungi. In Current Trends in Plant Disease Diagnostics and Management Practices; Kumar, P., Gupta, V.K., Tiwari, A.K., Kamle, M., Eds.; Springer: Cham, Germany, 2016 ; pp. $383-403$.

9. Pellegrino, C.; Gilardi, G.; Gullino, M.L.; Garibaldi, A. Detection of Phoma valerianellae in lamb's lettuce seeds. Phytoparasitica 2010, 38, 159-165. [CrossRef]

10. Zhang, X.; Wang, R.; Ning, H.; Li, W.; Bai, Y.; Li, Y. Evaluation and management of fungal-infected carrot seeds. Sci. Rep. 2020, 10, 10808. [CrossRef]

11. Zhao, Q.; Wu, J.; Zhang, L.; Yan, C.; Jiang, S.; Li, Z.; Sun, D.; Lai, Y.; Gong, Z. Genome-scale analyses and characteristics of putative pathogenicity genes of Stagonosporopsis cucurbitacearum, a pumpkin gummy stem blight fungus. Sci. Rep. 2020, 10, 18065. [CrossRef]

12. Chang, X.; Li, H.; Naeem, M.; Wu, X.; Yong, T.; Song, C.; Liu, T.; Chen, W.; Yang, W. Diversity of the seed-borne fungi and pathogenicity of fusarium species associated with intercropped soybean. Pathogens 2020, 9, 531. [CrossRef]

13. Gaur, A.; Kumar, A.; Kiran, R.; Kumari, P. Importance of seed-borne diseases of agricultural crops: Economic losses and impact on society. In Seed-Borne Diseases of Agricultural Crops: Detection, Diagnosis and Management, 1st ed.; Kumar, R., Gupta, A., Eds.; Springer: Singapore; Karnal, India, 2020; pp. 3-23. [CrossRef]

14. Abdulsalaam, S.; Shenge, K.C. Seed-borne pathogens on farmer-saved sorghum (Sorghum bicolor L.) seeds. J. Stored Prod. Postharvest Res. 2011, 2, 24-28.

15. Mathur, S.B.; Kongsdal, O. Common Laboratory Seed Health Testing Methods for Detecting Fungi, 1st ed.; International Seed Testing Association: Bassersdorf, Switzerland, 2003; pp. 1-317.

16. Mancini, V.; Romanazzi, G. Seed treatments to control seed-borne fungal pathogens of vegetable crops. Pest. Manage. Sci. 2014, 70, 860-868. [CrossRef] [PubMed]

17. Perczak, A.; Gwiazdowska, D.; Gwiazdowski, R.; Juś, K.; Marchwińska, K.; Waśkiewicz, A. The inhibitory potential of selected essential oils on Fusarium spp. growth and mycotoxins biosynthesis in maize seeds. Pathogens 2020, 9, 23. [CrossRef]

18. Thomas-Sharma, S.; Andrade-Piedra, J.; Carvajal Yepes, M.; Hernandez Nopsa, J.F.; Jeger, M.J.; Jones, R.A.C.; Kromann, P.; Legg, J.P.; Yuen, J.; Forbes, G.A. A risk assessment framework for seed degeneration: Informing an integrated seed health strategy for vegetatively propagated crops. Phytopathology 2017, 107, 1123-1135. [CrossRef] [PubMed]

19. Alvarez-Castellanos, P.P.; Bishop, C.D.; Pascual-Villalobos, M.J. Antifungal activity of the essential oil of flowerheads of garland chrysanthemum (Chrysanthemum coronarium) against agricultural pathogens. Phytochemistry 2001, 57, 99-102. [CrossRef]

20. Kordali, S.; Kotan, R.; Mavi, A.; Cakir, A.; Ala, A.; Yildirim, A. Determination of the chemical composition and antioxidant activity of the essential oil of Artemisia dracunculus and of the antifungal and antibacterial activities of Turkish Artemisia absinthium, A. dracunculus, Artemisia santonicum, and Artemisia spicigera essential oils. J. Agric. Food Chem. 2005, 53, 9452-9458. [CrossRef]

21. Romagnoli, C.; Bruni, R.; Andreotti, E.; Rai, M.K.; Vicentini, C.B.; Mares, D. Chemical characterization and antifungal activity of essential oil of capitula from wild Indian Tagetes patula L. Protoplasma 2005, 225, 57-65. [CrossRef]

22. Moumni, M.; Romanazzi, G.; Najar, B.; Pistelli, L.; Ben Amara, H.; Mezrioui, K.; Karous, O.; Chaieb, I.; Allagui, M.B. Antifungal activity and chemical composition of seven essential oils to control the main seedborne fungi of cucurbits. Antibiotics 2021, 10, 104. [CrossRef]

23. Della Pepa, T.; Elshafie, H.S.; Capasso, R.; De Feo, V.; Camele, I.; Nazzaro, F.; Scognamiglio, M.R.; Caputo, L. Antimicrobial and phytotoxic activity of Origanum heracleoticum and O. majorana essential oils growing in Cilento (southern Italy). Molecules 2019, 24, 2576. [CrossRef]

24. Riccioni, L.; Orzali, L.; Romani, M.; Annicchiarico, P.; Pecetti, L. Organic seed treatments with essential oils to control ascochyta blight in pea. Eur. J. Plant Pathol. 2019, 155, 831-840. [CrossRef]

25. Antunes, M.D.C.; Cavaco, A.M. The use of essential oils for postharvest decay control. Flavour. Fragr. J. 2010, 25, 351-366. [CrossRef]

26. Djioua, T.; Charles, F.; Freire, M., Jr.; Filgueiras, H.; Ducamp-Collin, M.; Sallanon, H. Combined effects of postharvest heat treatment and chitosan coating on quality of fresh-cut mangoes (Mangifera indica L.). Int. J. Food Sci.Technol. 2010, 45, 849-855. [CrossRef]

27. Shahi, S.K.; Patra, M.; Shukla, A.C.; Dikshit, A. Use of essential oil as botanical-pesticide against postharvest spoilage in Malus pumilo fruits. Biocontrol 2003, 48, 223-232. [CrossRef]

28. Newark, M.J.; Li, P.; Yang, X.P.; Paret, M.L.; Dufault, N.S. Comparing Stagonosporopsis spp. fungicide resistance profiles in Florida and East China cucurbit production systems. Plant Dis. 2020, 104, 129-136. [CrossRef]

29. Mao, X.; Wu, Z.; Bi, C.; Wang, J.; Zhao, F.; Gao, J.; Hou, Y.; Zhou, M. Molecular and biochemical characterization of pydiflumetofenresistant mutants of Didymella bryoniae. J. Agric. Food Chem. 2020, 68, 9120-9130. [CrossRef] [PubMed]

30. Moumni, M.; Mancini, V.; Allagui, M.B.; Murolo, S.; Romanazzi, G. Black rot of squash (Cucurbita moschata Duchesne) caused by Stagonosporopsis cucurbitacearum reported in Italy. Phytopathol. Mediterr. 2019, 58, 381-385. [CrossRef] 
31. Gimode, W.; Bao, K.; Fei, Z.; McGregor, C. QTL associated with gummy stem blight resistance in watermelon. Theor. Appl. Genet. 2020, 134, 573-584. [CrossRef] [PubMed]

32. Sivakumar, D.; Romanazzi, G. Use of essential oils to improve postharvest quality and control postharvest decay of tropical, subtropical, and temperate fruits. In Postharvest Pathology of Fresh Horticultural Produce; Palou, L., Smilanick, J.L., Eds.; CRC Press: New York, NY, USA, 2019; pp. 5-19. [CrossRef]

33. Fiori, A.C.G.; Schwan-Estrada, K.R.F.; Stangarlin, J.R.; Vida, J.B.; Scapim, C.A.; Cruz, M.E.S.; Pascholati, S.F. Antifungal activity of leaf extracts and essential oils of some medicinal plants against Didymella bryoniae. J. Phytopathol. 2000, 148, 483-487. [CrossRef]

34. Dalcin, M.S.; Cafee-Filho, A.C.; de Almeida Sarmento, R.; do Nascimento, I.R.; de Souza Ferreira, T.P.; de Sousa Aguiar, R.W.; dos Santos, G.R. Evaluation of essential oils for preventive or curative management of melon gummy stem blight and plant toxicity. $J$. Med. Plant. Res. 2017, 11, 426-432. [CrossRef]

35. Baka, Z.A.M. Biological control of the predominant seed-borne fungi of tomato by using plant extracts. Phytopathol. Pest. Manag. 2014, 1, 10-22.

36. Sahab, A.F.; Aly, S.; Hathout, A.S.; Ziedan, E.S.H.; Sabry, B.A. Application of some plant essential oils to control Fusarium isolates associated with freshly harvested maize in Egypt. J. Essent. Oil-Bear. Plants 2014, 17, 1146-1155. [CrossRef]

37. Szczerbanik, M.; Jobling, J.; Morris, S.; Holford, P. Essential oil vapours control some common postharvest fungal pathogens. Aust. J. Exp. Agric. 2007, 47, 103-109. [CrossRef]

38. Kumar, K.N.; Venkataramana, M.; Allen, J.A.; Chandranayaka, S.; Murali, H.S.; Batra, H.V. Role of Curcuma longa L. essential oil in controlling the growth and zearalenone production of Fusarium graminearum. LWT 2016, 69, 522-528. [CrossRef]

39. Matusinsky, P.; Zouhar, M.; Pavela, R.; Novy, P. Antifungal effect of five essential oils against important pathogenic fungi of cereals. Ind. Crop. Prod. 2015, 67, 208-215. [CrossRef]

40. Ferreira, F.M.D.; Hirooka, E.Y.; Ferreira, F.D.; Silva, M.V.; Mossini, S.A.G.; Machinski Jr, M. Effect of Zingiber officinale Roscoe essential oil in fungus control and deoxynivalenol production of Fusarium graminearum Schwabe in vitro. Food Addit. Contam. Part. A 2018, 35, 2168-2174. [CrossRef]

41. Perczak, A.; Gwiazdowska, D.; Marchwińska, K.; Juś, K.; Gwiazdowski, R.; Waśkiewicz, A. Antifungal activity of selected essential oils against Fusarium culmorum and F. graminearum and their secondary metabolites in wheat seeds. Arch. Microbiol. 2019, 201, 1085-1097. [CrossRef]

42. Mohamed, A.A.; El-Hefny, M.; El-Shanhorey, N.A.; Ali, H.M. Foliar application of bio-stimulants enhancing the production and the toxicity of Origanum majorana essential oils against four rice seed-borne fungi. Molecules 2020, 25, 2363. [CrossRef] [PubMed]

43. Van Der Wolf, J.M.; Birnbaum, Y.; Van Der Zouwen, P.S.; Groot, S.P.C. Disinfection of vegetable seed by treatment with essential oils, organic acids and plant extracts. Seed Sci. Technol. 2008, 36, 76-88. [CrossRef]

44. Xu, S.; Ni, Z.; Ma, L.; Zheng, X. Control of alternaria rot of cherry tomatoes by food-grade Laurus nobilis essential oil microemulsion. J. Food Saf. 2017, 37, e12286. [CrossRef]

45. Xu, S.; Yan, F.; Ni, Z.; Chen, Q.; Zhang, H.; Zheng, X. In vitro and in vivo control of Alternaria alternata in cherry tomato by essential oil from Laurus nobilis of Chinese origin. J. Sci. Food Agric. 2014, 94, 1403-1408. [CrossRef]

46. Daferera, D.J.; Ziogas, B.N.; Polissiou, M.G. The effectiveness of plant essential oils on the growth of Botrytis cinerea, Fusarium sp. and Clavibacter michiganensis subsp. Mich. J. Crop. Prot. 2003, 22, 39-44. [CrossRef]

47. Džamić, A.; Soković, M.; Ristić, M.; Grujić-Jovanović, S.; Vukojević, J.; kMarin, P.D. Chemical composition and antifungal activity of Salvia sclarea (Lamiaceae) essential oil. Arch. Biol. Sci. 2008, 60, 233-237. [CrossRef]

48. Kishore, G.K.; Pande, S.; Harish, S. Evaluation of essential oils and their components for broad-spectrum antifungal activity and control of late leaf spot and crown rot diseases in peanut. Plant Dis. 2007, 91, 375-379. [CrossRef] [PubMed]

49. Chen, Q.; Xu, S.; Wu, T.; Guo, J.; Sha, S.; Zheng, X.; Yu, T. Effect of citronella essential oil on the inhibition of postharvest Alternaria alternata in cherry tomato. J. Sci. Food Agric. 2014, 94, 2441-2447. [CrossRef]

50. Eke, P.; Adamou, S.; Fokom, R.; Nya, V.D.; Fokou, P.V.T.; Wakam, L.N.; Nwagab, D.; Boyom, F.F. Arbuscular mycorrhizal fungi alter antifungal potential of lemongrass essential oil against Fusarium solani, causing root rot in common bean (Phaseolus vulgaris L.). Heliyon 2020, 6, e05737. [CrossRef] [PubMed]

51. Orzali, L.; Valente, M.T.; Scala, V.; Loreti, S.; Pucci, N. Antibacterial activity of essential oils and Trametes versicolor extract against Clavibacter michiganensis subsp. michiganensis and Ralstonia solanacearum for seed treatment and development of a rapid in vivo assay. Antibiotics 2020, 9, 628. [CrossRef]

52. Orzali, L.; Forni, C.; Riccioni, L. Effect of chitosan seed treatment as elicitor of resistance to Fusarium graminearum in wheat. Seed Sci. Technol. 2014, 42, 132-149. [CrossRef]

53. Somda, I.; Leth, V.; Sereme, P. Antifungal effect of Cymbopogon citratus, Eucalyptus camaldulensis and Azadirachta indica oil extracts on sorghum seed-borne fungi. Asian J. Plant. Sci. 2007, 6, 1182-1189. [CrossRef]

54. Naveenkumar, R.; Muthukumar, A.; Sangeetha, G.; Mohanapriya, R. Developing eco-friendly biofungicide for the management of major seed-borne diseases of rice and assessing their physical stability and storage life. Comptes Rendus Biol. 2017, 340, 214-225. [CrossRef] 